Байкальский государственный университет, г. Иркутск, Российская Федерация

В. П. Чебунин

Байкальский государственный университет, г. Иркутск, Российская Федераиия

\title{
СОВРЕМЕННАЯ ОРГАНИЗАЦИЯ ПОХОРОННОГО ДЕЛА
}

\begin{abstract}
АНнотАцИя. Переход от плановой экономики социалистического периода к свободному рынку кардинально изменил сферу услуг, как и другие отрасли. Похоронный сервис также стал областью интересов предпринимателей. Это одна из общественно-важных сфер услуг, которая охватывает практически все население страны. В статье представлен обзор основных этапов развития похоронного дела в современной России. По итогу всех этапов развития похоронного дела становится ясно, что муниципалитеты оказались в тяжелых условиях неспособности содержать объекты ритуально-похоронного назначения и организовывать правильное выполнение всех процедур и норм. При отсутствии каких-либо гарантий для частных инвесторов похоронный сервис оказался в кризисном положении. Авторы утверждают, что на сегодняшний момент необходима модернизация отрасли, основанной на взаимовыгодных отношениях в условиях государственно-частного партнерства, так как органы местного самоуправления не смогут самостоятельно разрешить существующие проблемы в ритуальном сервисе. Для этого требуется разработать единую государственную концепцию совершенствования ритуально-похоронной отрасли.
\end{abstract}

кЛЮЧЕВЫЕ СЛОВА. Государственно-частное партнерство; похоронное дело; динамика рынка; инвестиции; законодательство.

ИНФОРМАЦИЯ О СТАТЬЕ. Дата поступления 11 февраля 2016 г.; дата принятия к печати 4 марта 2016 г.; дата онлайн-размещения 31 мая 2016 г.

P. Ye. Chestnov Baikal State University, Irkutsk, Russian Federation

V.P. Chebunin Baikal State University, Irkutsk, Russian Federation

\section{MODERN ORGANIZATION OF FUNERAL BUSINESS}

\begin{abstract}
Transition from planned economy of the socialist period to free market has radically changed the services sector like other sectors. The funeral service has also become an area of entrepreneurs' interests. It is one of the significant public services that covers almost the entire population of the country. The article presents a review of stages of the funeral business development in modern Russia. According to all stages of the funeral business development, it becomes clear that municipal entities have found themselves in severe terms of inability of maintaining the objects of ritual and funeral destination and arranging correct implementation of all procedures and standards. In the absence of any guarantees for private investors the funeral service found themselves in a critical state. The authors claim that at the present moment modernization of the sector is necessary, being based on mutually beneficial relations in the context of public-private partnership, as the local self-government bodies are unable to solve the existing problems the ritual service on their own account.
\end{abstract}

(C) П. Е. Честнов, В. П. Чебунин, 2016

\section{Baikal Research Journal}


KEYWORDS. Public-private partnership; funeral business; market dynamics; investments; legislation.

ARTICLE INFO. Received February 11, 2016; accepted March 4, 2016; available online May 31, 2016.

Переход от плановой экономики социалистического периода к свободному рынку кардинально изменил сферу услуг, как и другие отрасли [1; 2]. Похоронный сервис также стал областью интересов предпринимателей [3; 4]. Это одна из общественно-важных сфер услуг, которая охватывает практически все население страны. По данным Федеральной службы государственной статистики (далее - Росстат), в 2014 г. в Российской Федерации умерло 1912347 млн чел., а в их похоронах принимает участие приблизительно 35 млн россиян.

Ряд исследователей (Н. А. Платонова, П. Е. Уланов, А. В. Сулоев, М. Ю. Лимонад, С. Б. Якушин, Н. И. Жуков, С. В. Бондаренко, Г. Н. Сюткин, А. В. Мадьярова) выделяют три основных этапа развития похоронного дела в современной России и свойственных им модели функционирования отрасли:

1. Конец 80-х - начало 90-х гг. ХХ в. - связан с преобладающим принципом государственных похоронных служб, как было утверждено в советский период.

Исключительно государственные и муниципальные унитарные предприятия оказывали базовые услуги по погребению, обслуживали кладбища и иные объекты похоронного хозяйства. Новые правовые нормы не были созданы, отрасль работала по Инструкции о проведении похорон и содержании кладбищ от 1979 г., утвержденной Министерством жилищно-коммунального хозяйства РСФСР. Частное предпринимательство в сфере ритуальных услуг только зарождалось и ограничивалось, в основном, производством похоронных принадлежностей и намогильных сооружений, позже - предоставлением автокатафалков премиум-класса, привозимых предпринимателями из-за рубежа.

С приходом рыночной экономики в 1990-х гг. начал образовываться неоднородный рынок ритуальных услуг, происходит устранение монополии государства и возникает острая конкуренция между частными и муниципальным секторами. Ассортимент товаров и услуг существенно увеличился; частные похоронные фирмы выступили инициаторами внедрения ряда новых форм обслуживания, начали создавать свои агентские службы, салоны-магазины, ритуальные залы, службы останкоперевозки [5].

Конкурентная борьба выявила множество проблем и часто приводила к нарушению прав потребителей, криминализации отрасли. Государство было вынуждено обратить внимание на проблемы ритуального обслуживания. В 1993 г. утверждена первая федеральная целевая программа развития отрасли. С 1995 г. введено лицензирование деятельности по оказанию ритуальных услуг населению. Принят Закон РФ «О погребении и похоронном деле» ${ }^{1}$, утвержденный в начальной редакции, устанавливающий следующие положения:

- похоронное дело - вид деятельности, являющийся самостоятельным;

- устройство похоронного дела реализуется органами местного самоуправления (МСУ), органами исполнительной власти субъектов РФ, федеральными органами исполнительной власти;

- услуги по погребению предоставляются специализированными службами, организованными органами МСУ;

${ }^{1}$ О погребении и похоронном деле : федер. закон РФ от 12 янв. 1996 г. № 8ФЗ // Российская газета. 1996. 20 янв.

\section{Baikal Research Journal}


- граждане имеют право на целый комплекс общественных гарантий в части погребения, права лица о достойном отношении к его телу после смерти, бесплатное выделение участка земли для погребения и право на социальное пособие на погребение.

Получилось так, что закон породил одно из главных противоречий в развитии отрасли. С одной стороны, функции по погребению граждан были возложены на специализированные службы, представляющие собой, как правило, муниципальные унитарные предприятия. С другой, закон не раскрывал понятия специализированной службы и механизмов ее создания.

В тот же период был принят Указ Президента РФ от «О гарантиях прав граждан на предоставление услуг по погребению умерших» от 29 июня 1996 г. № 1001. Негосударственные (немуниципальные) похоронные службы, активно создаваемые в соответствии с норами гражданского законодательства в различных организационно-правовых формах, предлагали свои услуги населению, оспаривая преференции муниципальных предприятий.

Эти коллизии и юридические споры длились вплоть до принятия Закона РФ о защите конкуренции и последующего внесения разъяснений Президиума Высшего Арбитражного Суда (постановление от 23 сентября 2008 г.) и Федеральной антимонопольной службы России о равноправии всех участников рынка, а также неправомерности передачи земель кладбищ и функций местных администраций любым хозяйствующим субъектам.

2. Середина 1990-х — начало 2000-х гг. - характеризуется жестокой конкуренцией между муниципальными и частными похоронными службами, существенным ростом частного сектора рынка и его влиянием на развитие похоронной культуры, развитием похоронного хозяйства и его инфраструктуры за счет частных инвестиций, повышением профессионального уровня работников отрасли в связи с развитием профессионального образования и выставочного движения, объединением профессионалов в рамках общественных организаций [6].

В субъектах РФ начала формироваться региональная и местная нормативно-правовая база похоронного дела, проявился очевидный интерес негосударственного сектора рынка к созданию и эксплуатации объектов похоронного назначения, включая кладбища, крематории и похоронные дома. Тем не менее, регламенты работы похоронных комплексов городов были традиционно ориентированы на муниципальные специализированные службы.

3. В начале 2000 гг. появилось большое количество частных хозяйствующих субъектов на рынке ритуальных услуг. Последние годы официальная статистика отмечает долю негосударственных (немуниципальных) предприятий на уровне 55-60\% (по экспертным оценкам она еще больше и достигает 70 \% и более). Есть основания полагать, что многие малые частные предприятия и индивидуальные предприниматели не попадают в государственную отчетность [7].

На этом этапе частный сектор рынка продемонстрировал свою состоятельность и эффективность, способность оперативно и гибко реагировать в условиях нестабильной экономики. Многие частные компании хорошо зарекомендовали себя на рынке, превратившись в площадку для разработки и применения различных инноваций, освоения зарубежных технологий, нормотворческой и научно-образовательной работы, внедрения добровольных систем контроля качества.

Во многих крупных городах доля рынка, приходящаяся на частные похоронные службы, превысила 2/3 объема и более. Бизнесмены стали активно сооружать и вводить в эксплуатацию похоронные дома, ритуальные залы, производственные комплексы, автобазы, останкохранилища. За счет внебюджетных средств началось строительство крематориев в ряде городов, появилась практи-

\section{Baikal Research Journal}

электронный научный журнал Байкальского государственного университета 
ка передачи кладбищ на обслуживание частным похоронным компаниям по итогам конкурсов ${ }^{2}$.

В 2000-е гг. в отрасли произошли серьезные организационные перемены. С принятием Федерального закона РФ «Об общих принципах организации местного самоуправления» от 6 октября 2003 г. № 131-ФЗ функция по организации ритуальных услуг и содержанию мест захоронения была передана муниципалитетам. В 2003 г. в похоронном деле отменено лицензирование, что, по мнению многих экспертов, привело к снижению уровня обслуживания населения и стремительному росту недобросовестного предпринимательства [8].

$\mathrm{C}$ развитием законодательства о защите конкуренции серьезное воздействие на развитие рынка ритуально-похоронных услуг оказала Федеральная антимонопольная служба России. Юридическая практика показывает, что предприятия различных форм собственности на рынке услуг равноправны; муниципальные службы не имеют никаких дополнительных привилегий по отношению к другим респондентам рынка. Удалось выявить основные нарушения антимонопольного законодательства, которые приводили к рыночной нестабильности и коррупции, передаче части полномочий органов МСУ хозяйствующим субъектам.

На данном этапе стало ясно, что нормативно-правовая база предоставления ритуально-похоронных услуг, созданная в 1990 -х гг., сильно устарела и не отвечает сегодняшнему рынку, не учитывает сформировавшейся практики организации похорон и использование объектов похоронного назначения, быстрого развития современных производственных технологий. Важную консолидирующую роль в отрасли стал выполнять Союз похоронных организаций и крематориев (СПОК), решение о создании которого было принято на Международной конференции по вопросам управления похоронным делом в 2002 г.

Союз объединил более 100 организаций, как муниципальных, так и частных. В 2003 и 2007 гг. по инициативе и при активном участии СПОК проведены парламентские слушания в Государственной Думе РФ по вопросам применения и модернизации похоронного законодательства. Рекомендации слушаний раскрыли широкий спектр проблем развития отрасли и возможные пути их разрешения. Взаимодействие профессионального похоронного сообщества с государственными структурами вышло на самый высокий уровень - были созданы экспертные группы при Государственной Думе РФ и Федеральной антимонопольной службе России, представители ряда министерств и ведомств вошли в состав Президиума СПОК.

Тем не менее, совершенствование отрасли и ее правовой базы происходит крайне медленно; переработка закона о погребении носит длительный и противоречивый характер. Одной из причин этого является то, что на протяжении всех этапов развития отрасли актуальной оставалась проблема эффективного управления отраслью. Государство изначально законодательно не установило федеральный орган исполнительной власти, отвечающий за организацию ритуально-похоронной сферы услуг. Вопрос ведомственной принадлежности похоронного дела всегда оставался открытым ввиду наличия двух важнейших компонент:

- договорных отношений, связанных с приобретением услуг и товаров;

- сооружением и эксплуатацией объектов похоронного назначения, обслуживанием обширных территорий.

Традиционно часть вопросов отрасли брал на себя Минбыт России, часть - Минстрой России. Еще одна существенная особенность отрасли - плотное взаимодействие с медицинскими учреждениями, курируемыми Минздравом. Работа кладбищ

${ }^{2}$ На мертвой точке // Российская газета. 2010. 6 авг.

\section{Baikal Research Journal}

электронный научный журнал Байкальского государственного университета 
и иных объектов похоронного назначения регламентируется санитарно-гигиеническими нормами и правилами, утверждаемыми Главным государственным санитарным врачом РФ [9].

В ходе административных реформ профильное министерство так и не было определено, а с совершенствованием законодательной базы о местном самоуправлении и передачи вопроса организации ритуально-похоронных услуг и содержания в достойном состоянии земли для захоронения к полномочиям органов местного самоуправления государство отстранилось от заботы и помощи в сфере захоронения граждан и улучшении похоронного хозяйства. Свертывание системы государственного надзора вызвало снижение качества в сфере ритуального обслуживания. По этому поводу глава Министерства строительства и жилищно-коммунального хозяйства РФ М. Мень сообщил, что до сих пор нормативно-правовая база похоронного дела не модернизирована в должной степени, несмотря на масштабную работу в этом направлении со стороны профессионального похоронного сообщества, ряда министерств и ведомств. В России так и не выработана единая государственная политика развития сферы ритуального обслуживания населения ${ }^{3}$.

Муниципалитеты оказались в тяжелых условиях неспособности содержать объекты ритуально-похоронного назначения и организовывать правильное выполнение всех процедур и норм. Частные инвесторы оказались в кризисном положении из-за отсутствия каких-либо гарантий в похоронном сервисе. Стало понятно, что без правового регулирования и привлечения государственных и рыночных средств нормальное функционирование отрасли невозможно [10].

По нашему мнению, построение грамотных отношений между государством и частными предпринимателями по модернизации похоронного сервиса позволит сделать новый прорыв к построению новой похоронной инфраструктуры и внедрению современных форм обслуживания. При этом требуется законодательно установить регламенты, что позволит создать социальную защищенность населения и даст гарантии для предпринимателей $[11 ; 12]$. У нас есть основания утверждать, что на сегодняшний момент необходима модернизация отрасли, которая будет основана на взаимовыгодных отношениях в условиях государственно-частного партнерства. Стало ясно, что органы местного самоуправления не смогут разрешить проблемы ритуального сервиса. Требуется разработать единую государственную концепцию совершенствования ритуально-похоронной отрасли. При этом необходимо отметить, что серьезных изменений требует нормативно-правовая работа.

Объем реализации услуг по погребению естественным образом привязан к показателю смертности населения. В этом смысле, на макроуровне рынок ритуальных услуг конечен и ограничивается количеством умерших, которых необходимо похоронить. Рост объемов реализации в отрасли может происходить за счет продажи более качественных и дорогих похоронных принадлежностей, расширения ассортимента основных и дополнительных услуг, предоставления мест захоронения нового типа на коммерческой основе. Переход к новому механизму сотрудничества и саморегулирования в государственно-частном партнерстве на сегодняшний день является реальной возможностью в усовершенствовании похоронной отрасли.

Теперь рассмотрим количественные характеристики отрасли. Общие представления о рынке ритуальных услуг можно получить из анализа демографических

${ }^{3}$ URL : http://echo.msk.ru/blog/advokat_sazonov/more/1333608.html.

\section{Baikal Research Journal}

электронный научный журнал Байкальского государственного университета 
показателей (табл. 1). Так, после «провальных» 1995-2011 гг. ситуация начинает выправляться, но до показателей 50-70-х гг. ХХ в. еще далеко.

Таблица 1

Статистика демографических показателей в Российской Федерации (по состоянию на 9 июня 2015 г.)

\begin{tabular}{|r|r|r|r|r|r|r|}
\hline Годы & \multicolumn{3}{|c|}{ Общее количество, чел. } & \multicolumn{2}{|c|}{ На 1 000 чел. населения } \\
\cline { 2 - 7 } & родившихся & умерших & $\begin{array}{c}\text { естественный } \\
\text { прирост }\end{array}$ & родившихся & умерших & $\begin{array}{c}\text { естесвенный } \\
\text { прирост }\end{array}$ \\
\hline 1950 & 2745997 & 1031010 & 1714987 & 26,9 & 10,1 & 16,8 \\
\hline 1960 & 2782353 & 886090 & 1896263 & 23,2 & 7,4 & 15,8 \\
\hline 1970 & 1903713 & 1131183 & 772530 & 14,6 & 8,7 & 5,9 \\
\hline 1980 & 2202779 & 1525755 & 677024 & 15,9 & 11,0 & 4,9 \\
\hline 1990 & 1988858 & 1655993 & 332865 & 13,4 & 11,2 & 2,2 \\
\hline 1995 & 1363806 & 2203811 & -840005 & 9,3 & 15,0 & $-5,7$ \\
\hline 2000 & 1266800 & 2225332 & -958532 & 8,7 & 15,3 & $-6,6$ \\
\hline 2001 & 1311604 & 2254856 & -943252 & 9,0 & 15,6 & $-6,6$ \\
\hline 2002 & 1396967 & 2332272 & -935305 & 9,7 & 16,2 & $-6,5$ \\
\hline 2003 & 1477301 & 2365826 & -888525 & 10,2 & 16,4 & $-6,2$ \\
\hline 2004 & 1502477 & 2295402 & -792925 & 10,4 & 15,9 & $-5,5$ \\
\hline 2005 & 1457376 & 2303935 & -846559 & 10,2 & 16,1 & $-5,9$ \\
\hline 2006 & 1479637 & 2166703 & -687066 & 10,3 & 15,1 & $-4,8$ \\
\hline 2007 & 1610122 & 2080445 & -470323 & 11,3 & 14,6 & $-3,3$ \\
\hline 2008 & 1713947 & 2075954 & -362007 & 12,0 & 14,5 & $-2,5$ \\
\hline 2009 & 1761687 & 2010543 & -248856 & 12,3 & 14,1 & $-1,8$ \\
\hline 2010 & 1788948 & 2028516 & -239568 & 12,5 & 14,2 & $-1,7$ \\
\hline 2011 & 1796629 & 1925720 & -129091 & 12,6 & 13,5 & $-0,9$ \\
\hline 2012 & 1902084 & 1906335 & -4251 & 13,3 & 13,3 & 0,0 \\
\hline 2013 & 1895822 & 1871809 & 24013 & 13,2 & 13,0 & 0,2 \\
\hline 2014 & 1942683 & 1912347 & 30336 & 13,3 & 13,1 & 0,2 \\
\hline
\end{tabular}

Составлено по: URL : www.gks.ru.

На данный момент в отрасли работают более чем 12,1 тыс. похоронных организаций (статистика за 2014 г.), В Российской Федерации используются 18 крематориев (табл. 2). В 2014 г. зафиксировано 1865500 захоронений (97 \% от количества умерших); 7 \% приходится на кремацию.

Захоронения в землю и кремации выполняют одинаковую функцию, при этом цена на погребения примерно одинакова (рис. 1).

Объем реализации в 2014 г. оценивается Росстатом более чем в 30,1 млрд р. (рис. 2), но в Иркутской области захоронения осуществляются только в землю, так как отсутствует крематорий. Уверены, что в реальности объем продаж рынка значительно выше данного показателя. Проверим это на примере основного набора услуг, используя показатели, приведенные в табл. 3.

Для расчета реальной емкости рынка возьмем среднюю стоимость похорон на уровне 35 тыс. р. (данные СПОК). Стандартный необходимый пакет услуг включает услуги агента, подготовку тела к погребению, транспортное обслуживание, предоставление ритуального зала, комплект похоронных принадлежностей (облачение умершего, гроб с постелью, венок). Стоимости услуг по захоронению гроба с телом и кремации с последующим предоставлением урны примем равными на уровне 7 тыс. p.

\section{Baikal Research Journal}

электронный научный журнал Байкальского государственного университета 
Таблица 2

Сведения Росстата о крематориях в Российской Федерации в 2014 г.

\begin{tabular}{|c|c|c|}
\hline Федеральный округ & $\begin{array}{c}\text { Число } \\
\text { крематориев }\end{array}$ & $\begin{array}{c}\text { Количество } \\
\text { кремаций за год }\end{array}$ \\
\hline Центральный & 5 & 68430 \\
\hline Москва & 3 & 52771 \\
\hline Балашиха (Московская обл.) & 1 & 8785 \\
\hline Тула & 1 & 6874 \\
\hline Северо-Западный & 1 & 33795 \\
\hline Санкт-Петербург & 1 & 33795 \\
\hline Южный & 2 & 1504 \\
\hline Ростов-на-Дону & 1 & 834 \\
\hline Волгоград & 1 & 670 \\
\hline Уральский & 4 & 10811 \\
\hline Екатеринбург & 1 & 8343 \\
\hline Нижний Тагил (Свердловская обл.) & 1 & 1392 \\
\hline Сургут (Ханты-Мансийский автономный округ) & 1 & 285 \\
\hline Челябинск & 1 & 791 \\
\hline Сибирский & 3 & 8901 \\
\hline Новокузнецк (Кемеровская обл.) & 1 & 4628 \\
\hline Норильск (Красноярский край) & 1 & 964 \\
\hline Иркутская обл. & $1(?)$ & 3309 \\
\hline Дальневосточный & 3 & 5028 \\
\hline Артем (Приморский край) & 1 & 1684 \\
\hline Владивосток & 1 & 1649 \\
\hline Хабаровск & 1 & 1695 \\
\hline Bcero & 18 & 128469 \\
\hline
\end{tabular}

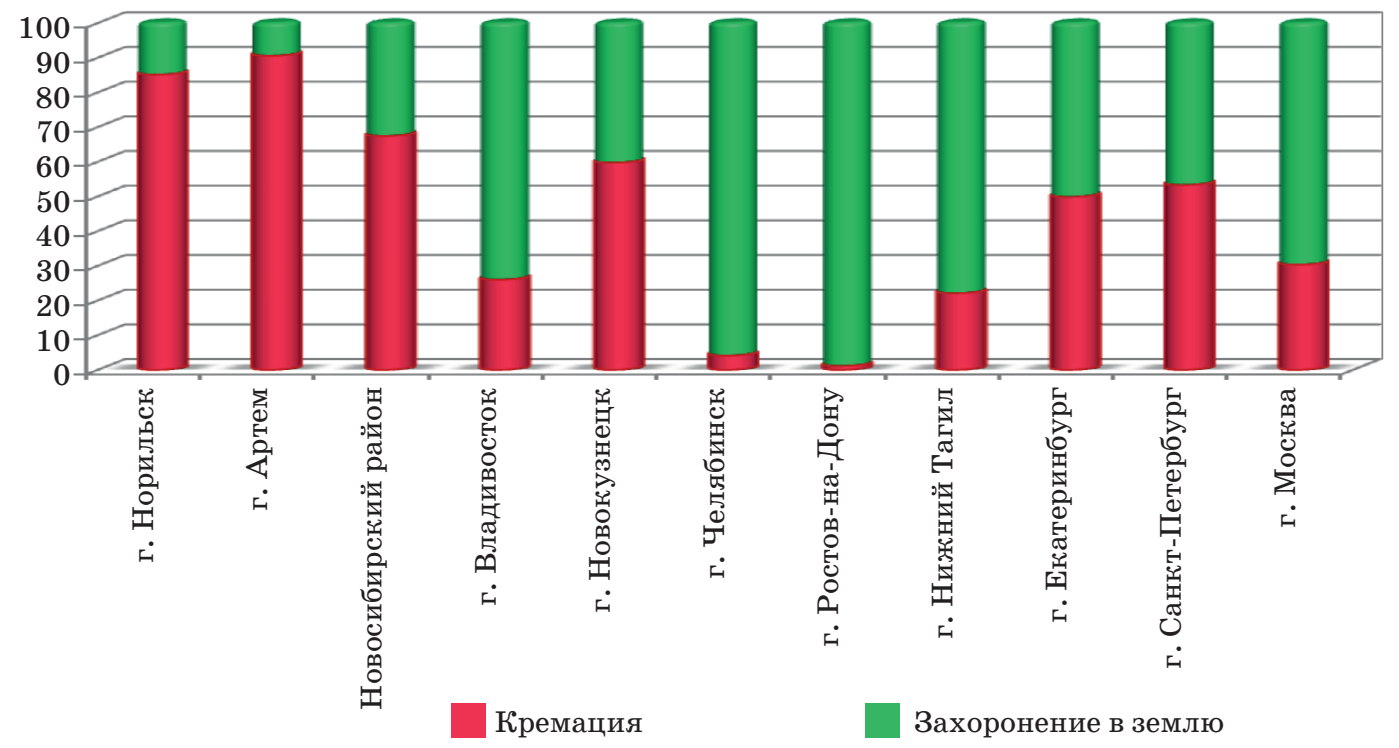

Рис. 1. Объемь продаж по услугал погребения, \%

\section{Baikal Research Journal}




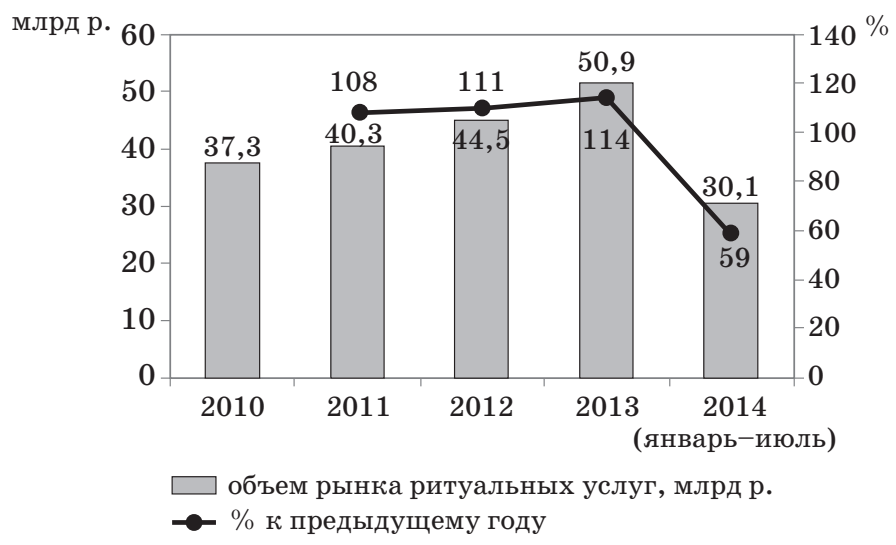

Рис. 2. Объемы рынка ритуальных услуг в 2010-2014 гг.

Таблица 3

\section{Показатели для расчета реальной емкости рынка ритуальных услуг} в Российской Федерации в ценах 20142.

\begin{tabular}{|l|r|}
\hline \multicolumn{1}{|c|}{ Показатель } & Величина \\
\hline Потенциальный рынок $V_{p}$, чел. & 1912347 \\
\hline Реальный (доступный) рынок $V$, чел. & 1865500 \\
\hline Средняя стоимость услуг по организации похорон $P_{f}, \mathrm{p}$. & 26000 \\
\hline Средняя стоимость услуг по захоронению гробом $P_{g}, \mathrm{p}$. & 9000 \\
\hline Средняя стоимость кремации с предоставлением урны $P_{c r}, \mathrm{p}$. & 7000 \\
\hline Средняя стоимость похорон $P$, р. & 35000 \\
\hline Средняя стоимость намогильного сооружения с установкой $P_{m}, \mathrm{p}$. & 20800 \\
\hline Средняя стоимость разовой уборки места захоронения $P_{c l}, \mathrm{p}$. & 1500 \\
\hline Доля кремаций, \% & 7 \\
\hline Доля заказов на установку намогильных сооружений, $\%$ & 50 \\
\hline Доля заказов на уход за местом захоронения, $\%$ & 10 \\
\hline
\end{tabular}

При средней стоимости стандартного памятника (небольшая стела с цветником) 16 тыс. р. учтем 30 \% на расходы по установке, получим 20800 р.

Для расчета реальной емкости рынка ритуальных услуг $S$ за годовой период возьмем следующую формулу:

$$
S=V P+0,5 V P_{m}+0,1 V P_{c l} .
$$

Таким образом, $S$ составит 84,97 млрд р. $(1865500 \cdot 35000+932750 \cdot 20800+$ $+186500 \cdot 1500)$. Важно отметить, что данный расчет не учитывает расходов на услуги по организации и проведению поминальных трапез, предоставлению колумбарных ниш, изготовлению и установке оград и других услуг, т. е. реальный показатель емкости рынка еще выше и может достигать 90 млрд р. и более.

Структурно-функциональная схема организации похоронного дела в Российской Федерации (рис. 3) на общегосударственном уровне включает ряд министерств и ведомств: Минрегион России, Минэкономразвития России, Минздрав России, Минобороны России, Минобрнауки, Роспотребнадзор,Росстандарт, Федеральную антимонопольную службу России и др. С ними взаимодействуют общественные и научно-образовательные организации.

\section{Baikal Research Journal}




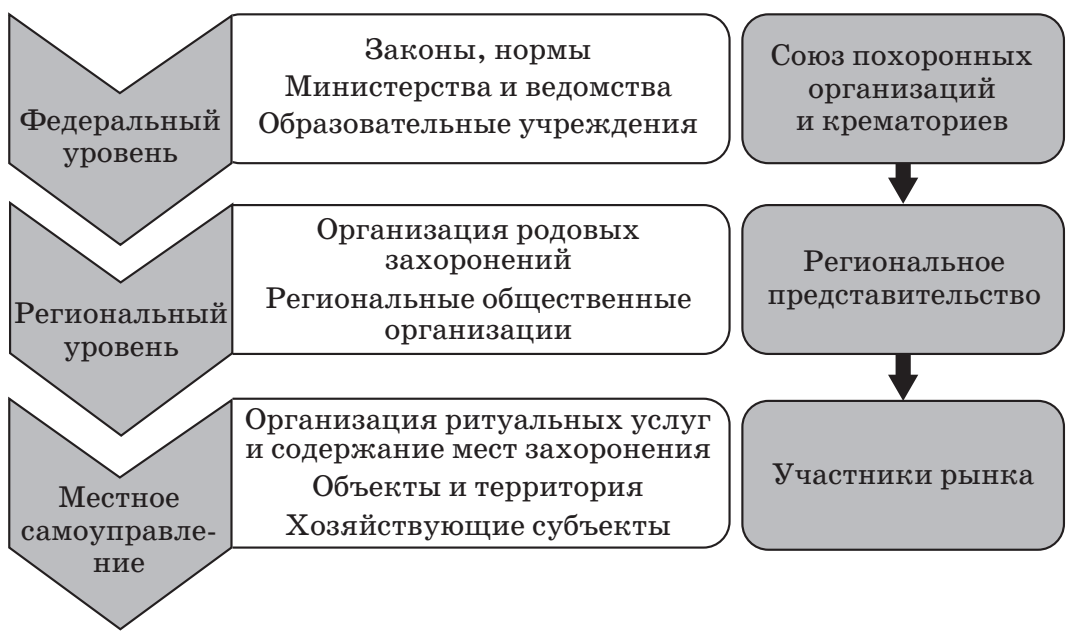

Рис. 3. Структурно-функциональная схела организации похоронного дела в Российской Федерации

На уровне субъектов РФ регулирование отрасли практически не осуществляется. Этот пробел необходимо восполнить, вернув региональные органы исполнительной власти в систему управления отраслью и наделив их определенными полномочиями.

Основная ответственность за организацию похоронного дела лежит на органах МСУ, которые в настоящее время не имеют достаточных ресурсов для обеспечения качественного похоронного сервиса и четкого выполнения социальных гарантий по погребению. Кроме того, во многих муниципалитетах по-своему трактуют нормы Закона о погребении, что приводит к нарушению антимонопольного законодательства.

Федеральная антимонопольная служба России указала на следующие особенности, препятствующие развитию рынка ритуальных услуг:

1. Основные проблемы присутствуют в крупных городах в условиях дефицита мест захоронения.

2. Еще одной из причин является неверное применение закона о погребении.

3. Ритуальные услуги в городах относятся к рынкам с недобросовестной и неразвитой конкуренцией.

4. Часто присутствуют факты создания искусственного доминирования отдельных служб, это влияет на деятельность других субъектов.

5. В муниципальных образованиях часто отсутствуют нормативно-правовые акты, корректирующие работу ритуальной сферы.

В результате нами были выявлены следующие пункты, на которые требуется обратить внимание:

1. Недостаточное финансирование на содержание мест захоронения.

2. Нехватка земельных участков в мегаполисах.

3. Противостояние между медициной и ритуальной сферой (больничные морги организовывают ритуальный бизнес, не имея навыков в данной отрасли).

4. Несовершенство нормативно-правовой базы в ритуальной сфере.

5. Многомиллиардная коррупция в ритуально-похоронной сфере. Отсутствие контроля над похоронными службами вызывают избыток рынка.

Мы предполагаем, что для перспективного развития данной отрасли необходимо:

- повышение профессионального образования работников (курсы);

- продвижение новых товаров и услуг;

- развитие кремации и новых методов безопасного захоронения;

\section{Baikal Research Journal}


- модернизация и реконструкция ритуальных объектов;

- привлечение частного бизнеса к строительству негосударственных кладбищ и прилегающих сооружений.

\section{Список использованной литературы}

1. Сфера социально значимых услуг: теоретические и прикладные аспекты деятельности организаций : в 2 ч. / под общ. ред. Т. Д. Бурменко, О. Н. Баевой. - Иркутск : Изд-во БГУЭП, 2012. - Ч. 1. - 380 с.

2. Институциональные изменения в сфере социально значимых услуг / Т. Д. Бурменко, В. Ю. Баганов, О. Н. Баева [и др.] ; отв. ред. Т. А. Кондрацкая. - Иркутск : Изд-во БГУЭП, 2013. -268 c.

3. Чонка А. К. Государственно-частное партнерство: симбиоз государства и бизнеса / А. К. Чонка // Бюджет. - 2009. - № 7. - С. 56-61.

4. Шефов С. А. Психология горя : учеб. пособие / С. А. Шефов. - СПб. : Речь, 2007. — 320 с.

5. Акитоби Б. Государственные инвестиции и государственно-частные партнерства : пер. с англ. / Б. Акитоби, Р. Хемминг, Г. Шварц. - Вашингтон : Междунар. валют. фонд, 2007. - 30 с. - (Вопросы экономики, № 40).

6. Бруссер П. А. Государственно-частное партнерство - новый механизм привлечения инвестиций / П. А. Бруссер, С. В. Рожкова // Рынок ценных бумаг. — 2007. — № 2. - С. 25-35.

7. Варнавский В. Г. Альянс на неопределенный срок / В. Г. Варнавский // ФельдПочта. - 2004. - № 29. - С. 5-11.

8. Современные скорбные и траурные ритуалы России. Гражданский требник (сб. ритуалов) : учеб. пособие / под ред. М. Ю. Лимонада, П. Е. Уланова. - М. : Изд. А. С. Акчурин, 2006. -209 c.

9. Горев В. П. Специфика формирования конкурентного процесса в экономики России / В. П. Горев // Известия Иркутской государственной экономической академии. - 2005. № 1 (42). - С. 8-13.

10. Сильвестров С. А. Партнерство государства и частного сектора / С. А. Сильвестров // Экономика России: XXI век. - 2005. - № 18. - С. 54-56.

11. Сюткин Н. Г. Основы ритуально похоронного дела : учеб. пособие / Н. Г. Сюткин. М. : Альфа-M, 2009. - 320 с.

12. Gerrard Michael B. Public-Private Partnerships / Michael B. Gerrard // Finance and Development. - 2001. - Vol. 38, № 3. - P. 48-51.

\section{References}

1. Burmenko T. D., Bayeva O. N. (eds). Sfera sotsialno znachimykh uslug: teoreticheskie $i$ prikladnye aspekty deyatelnosti organizatsii [Scope of Socially Important Services: Theoretical and Applied Aspects of Company's Activities]. Irkutsk, Baikal State University of Economics and Law Publ., 2012. Pt. 1. 380 p.

2. Burmenko T. D., Baganov V. Yu., Bayeva O. N. et al.; Kondratskaya T. A. (ed.). Institutsional'nye izmeneniya $v$ sfere sotsial'no znachimykh uslug [Institutional Changes in The Sphere of Socially Significant Services]. Irkutsk, Baikal State University of Economics and Law Publ., 2013. $268 \mathrm{p}$.

3. Chonka A. K. Public-private partnership: a symbiosis of government and business . Byudzhet $=$ Budget, 2009, no. 7, pp. 56-61. (In Russian).

4. Shefov S. A. Psikhologiya gorya [Psychology of grief]. Saint Petersburg, Rech' Publ., 2007. $320 \mathrm{p}$.

5. Aktiobi B., Hemming R., Schwartz G. Public Investment and Public-Private Partnerships. Washington, D.C., International Monetary Fund, 2007. 30 p.

6. Brusser P. A., Rozhkova C. B. Public-private partnership as a new mechanism of investment attraction. Rynok tsennykh bumag = Securities Market, 2007, no. 2, pp. 25-35. (In Russian).

7. Varnavsky V. G. Alliance for an uncertain period. Fel'dPochta = Courier Service, 2004, no. 29, pp. 5-11. (In Russian).

8. Limonad M. Yu., Ulanov P. E. (eds). Sovremennye skorbnye i traurnye ritualy Rossii. Grazhdanskii trebnik [Modern mournful and funeral rituals of Russia. The civil mass-Book]. Moscow, A. S. Akchurin Publ., 2006. 209 p.

\section{Baikal Research Journal}


9. Gorev V. P. Specific forming of competition process in Russian economics. Izvestiya Irkutskoi gosudarstvennoi ekonomicheskoi akademii = Bulletin of Irkutsk State Economics Acade$m y, 2005$, no. 1 (42), pp. 8-13. (In Russian).

10. Silvestrov S. A. Partnership of government and private sectors. Ekonomika Rossii: $X X I$ vek = Russia's Economy: XXI century, 2005, no. 18, pp. 54-56. (In Russian).

11. Syutkin N. G. Osnovy ritual'no pokhoronnogo dela [Basics of the ritual-funeral business]. Moscow, Al'fa-M Publ., 2009. 320 p.

12. Gerrard Michael B. Public-Private Partnerships. Finance and Development, 2001, vol. 38 , no. 3 , pp. 48-51.

\section{Информация об авторах}

Честнов Павел Евгеньевич - аспирант, кафедра экономики предприятий и предпринимательской деятельности, Байкальский государственный университет, 664003, г. Иркутск, ул. Ленина, 11, e-mail: evgpavel@yandex.ru.

Чебунин Виктор Петрович - кандидат экономических наук, доцент, кафедра экономики предприятий и предпринимательской деятельности, Байкальский государственный университет, 664003, г. Иркутск, ул. Ленина, 11, e-mail: hebvik@mail.ru.

\section{Authors}

Pavel Ye. Chestnov - PhD Student, postgraduate student, Professor, Chair of Business Economy and Entrepreneurship, Baikal State University, 11 Lenin St., 664003, Irkutsk, Russian Federation; e-mail: evgpavel@yandex.ru.

Viktor P. Chebunin - PhD in Economics, Associate Professor, Chair of Business Economy and Entrepreneurship, Baikal State University, 11 Lenin St., 664003, Irkutsk, Russian Federation; e-mail: hebvik@mail.ru.

\section{Библиографическое описание статьи}

Честнов П. Е. Современная организация похоронного дела» / П. Е. Честнов, В. П. Чебунин // Baikal Research Journal. — 2016. — T. 7, № 3. — DOI : 10.17150/2411-6262.2016.7(3).12.

\section{Reference to article}

Chestnov P. Ye., Chebunin V. P. Modern organization of funeral business. Baikal Research Journal, 2016, vol. 7, no. 3. DOI : 10.17150/2411-6262.2016.7(3).12. (In Russian).

\section{Baikal Research Journal}

